\title{
CARDIOPULMONARY BYPASS AND CIRCULATORY ARREST INCREASE ENDOTHELIN-1 PRODUCTION AND RECEPTOR EXPRESSION IN THE LUNG
}

Paul M. Kirshbom, MD

Stella O. Page ${ }^{b}$

M. Todd Jacobs, MD ${ }^{a}$

Steven S. L. Tsui, FRCS ${ }^{\text {a }}$

Elizabeth Bello, $\mathrm{MD}^{\mathrm{b}}$

Ross M. Ungerleider, $\mathrm{MD}^{\mathrm{a}}$

Debra A. Schwinn, MD ${ }^{a, b, c}$

J. William Gaynor, MD ${ }^{\mathrm{d}}$
Background: Endothelin-1 has been shown to be a mediator of pulmonary hypertension after cardiopulmonary bypass and deep hypothermic circulatory arrest. It is not known whether the mechanism is increased production of endothelin-1 or alterations in expression of endothelin-1 receptors in the lung. This study was designed to test the hypothesis that circulatory arrest increases endothelin-1 mRNA levels and endothelin-1 receptor expression in the Iung. Methods and results: Twenty-four piglets ( 7 to 30 days old) were studied randomly either at baseline (controls, $n=12$ ) or after cardiopulmonary bypass with 30 minutes of circulatory arrest (deep hypothermic circulatory arrest, $n=12$ ). Lungs and pulmonary arteries were harvested immediately after hemodynamic data collection. Deep hypothermic circulatory arrest significantly increased pulmonary vascular resistance $(p<0.01)$. Deep hypothermic circulatory arrest also produced a significant increase in endothelin-1 mRNA levels in the pulmonary arteries $(149 \pm 55 \mathrm{pg}$ vs $547 \pm 111 \mathrm{pg}, p=0.007)$. There was no significant change in the pulmonary parenchymal endothelin-1 mRNA levels $(4102 \pm 379$ pg vs $4623 \pm 308 \mathrm{pg}, p=0.32)$. Ligand binding studies of the lung parenchyma revealed a single specific endothelin-1 binding site with an $\mathrm{EC}_{50}$ value (effective concentration causing $50 \%$ of the maximum response) of about $1 \times 10^{-8} \mathrm{~mol} / \mathrm{L}$, consistent with the endothelin B subtype. Deep hypothermic circulatory arrest resulted in a significant increase in the number of endothelin-1 receptors in the lung $(109 \pm 6 \mathrm{fmol} / \mathrm{mg}$ total protein to $135 \pm 9 \mathrm{fmol} / \mathrm{mg}$ total protein, $p=0.02)$. Conclusions: Deep hypothermic circulatory arrest increases production of endothelin-1 by the pulmonary vascular endothelium. Endothelin-1 production in the pulmonary parenchyma does not change. Expression of endothelin $B$ receptors in the pulmonary parenchyma also increases after cardiopulmonary bypass with deep hypothermic circulatory arrest. This study supports the hypothesis that deep hypothermic circulatory arrest results in pulmonary vascular endothelial activation with increased endothelin-1 mRNA production. (J Thorac Cardiovase Surg 1997;113:777-83)
From the Departments of Surgery, ${ }^{a}$ Anesthesiology, ${ }^{b}$ and Pharmacology, ${ }^{c}$ Duke University Medical Center, Durham, N.C., and the Department of Pediatric Cardiothoracic Surgery, ${ }^{d}$ Children's Hospital of Philadelphia, Philadelphia, Pa.

Supported in part by American Heart Association grant 95014360.

Received for publication August 30, 1996; revisions requested Oct. 21, 1996; revisions received Nov. 14, 1996; accepted for publication Nov. 19, 1996.

Address for reprints: J. William Gaynor, MD, Pediatric Cardiothoracic Surgery, Children's Hospital of Philadelphia, 34th St. and Civic Center Blvd., Philadelphia, PA 19104.

Copyright (C) 1997 by Mosby-Year Book, Inc.

$0022-5223 / 97 \$ 5.00+0 \quad \mathbf{1 2 / 1 / 7 9 3 3 8}$
Cardiopulmonary bypass (CPB) with deep hypo$\checkmark$ thermic circulatory arrest (DHCA) often results in clinically significant increases in pulmonary vascular resistance (PVR), particularly in infants and children. ${ }^{1-4}$ Although clinically significant pulmonary dysfunction is uncommon, it can cause considerable morbidity and mortality in patients with impaired right ventricular function. The mechanisms underlying this response are still unclear.

Previous studies have demonstrated the central role of the pulmonary vascular endothelium both in the maintenance of normal pulmonary vasomotor tone and in the hypertensive response to $\mathrm{CPB} .^{2,5-9}$ 
Impaired endothelium-dependent pulmonary vasodilation after CPB with DHCA has been demonstrated both in experimental animals and in children undergoing repair of congenital cardiac defects. ${ }^{2,7}$ Increased production of endothelium-derived vasoconstrictors including endothelin-1 (ET-1) and thromboxane $\mathrm{A}_{2}$ has also been reported after $\mathrm{CPB}$ with DHCA. $5,8,10$

ET-1 is a 21-amino acid polypeptide that is the most potent vasoconstrictor known. Plasma levels of ET-1 are elevated after CPB, ${ }^{11,12}$ and blockade of ET-1-converting enzyme during CPB attenuates the post-DHCA pulmonary hypertensive response. ${ }^{6}$ ET-1 is produced and released by endothelial cells with no intracellular storage. ${ }^{13}$ Two ET-1 receptor subtypes are expressed in vascular tissue. The $\mathrm{ET}_{\mathrm{A}}$ receptor is expressed primarily by vascular smooth muscle cells whereas the $\mathrm{ET}_{\mathrm{B}}$ receptor is expressed by both endothelial cells and vascular smooth muscle cells. ${ }^{14}$ Activation of the $\mathrm{ET}_{\mathrm{A}}$ receptor results in smooth muscle cell contraction and vasoconstriction because of phospholipase $\mathrm{C}$ stimulation and secondary increases in intracellular calcium levels. Stimulation of $\mathrm{ET}_{\mathrm{B}}$ receptors on endothelial cells typically results in vasodilation through a nitric oxide-mediated pathway. ${ }^{14}$ The relatively smaller numbers of $\mathrm{ET}_{\mathrm{B}}$ receptors found on vascular smooth muscle cells mediate vasoconstriction in a manner similar to that of $\mathrm{ET}_{\mathrm{A}}{ }^{15}$

These studies were designed to test two hypotheses: (1) CPB with DHCA increases ET-1 production by either the pulmonary vascular endothelium or the pulmonary parenchyma and (2) CPB with DHCA increases pulmonary ET-1 receptor expression. ET-1 is transcriptionally regulated with no intracellular storage, thus endothelial production of ET-1 can be quantitated by tissue ET-1 messenger ribonucleic acid (mRNA) levels.

\section{Methods}

Twenty-four DeKalb piglets ( 7 to 28 days old) were randomized into either the control or DHCA group. Control animals were studied after anesthesia and instrumentation were accomplished and DHCA animals also underwent $\mathrm{CPB}$ with DHCA as will be described. There was not a significant difference in the mean ages or weights of animals in the two groups.

Anesthesia and operation. The animals were premedicated with intramuscular ketamine $(20 \mathrm{mg} / \mathrm{kg})$ and acepromazine $(1 \mathrm{mg} / \mathrm{kg})$, intubated, and placed on mechanical ventilation (Sechrist infant ventilator, model IV-100B). Anesthesia was maintained with fentanyl (100 $\mu \mathrm{g} / \mathrm{kg}$ bolus and $50 \mu \mathrm{g} / \mathrm{kg}$ per hour continuous infusion) and pancuronium $(0.3 \mu \mathrm{g} / \mathrm{kg})$. The ventilator was set with a positive inspiratory pressure of $25 \mathrm{~mm} \mathrm{Hg}$ and a positive end-expiratory pressure of $3 \mathrm{~mm} \mathrm{Hg}$. Respiratory rate and inspired oxygen fraction were titrated to maintain an arterial carbon dioxide tension of 35 to $45 \mathrm{~mm} \mathrm{Hg}$ and oxygen tension of 150 to $250 \mathrm{~mm} \mathrm{Hg}$. Sodium bicarbonate $(8.5 \%)$ was used to maintain a base excess between -3 and $3 \mathrm{mmol} / \mathrm{L}$. All animals received methylprednisolone (25 $\mathrm{mg} / \mathrm{kg}$ intravenously) before operation.

A femoral arterial line was placed for blood pressure monitoring and arterial blood gas sampling. A nasopharyngeal temperature probe (YSI-400, Yellow Springs Instruments) was inserted and a median sternotomy was done. The pericardium was opened and a $10 \mathrm{~mm}$ ultrasonic flow probe placed on the main pulmonary artery (Transonic Systems Inc., Ithaca, N.Y.). Micromanometers ( $3 F$, Millar Instruments Inc., Houston, Tex.) were placed in the pulmonary artery and left atrium.

All animals received humane care in accordance with the "Guide for the Care and Use of Laboratory Animals" published by the National Institutes of Health (NIH Publication No. 85-23, revised 1985) and as approved by the institutional animal care and use committee.

Protocol. DHCA-group animals underwent CPB with 30 minutes of DHCA as will be described. Data were collected at baseline (before $\mathrm{CPB}$ ) and 15 minutes after separation from CPB. Control animals underwent anesthesia and instrumentation followed by data collection at baseline. After data collection at the last data point, all animals were killed. The pulmonary arteries and lungs were then excised and snap frozen in liquid nitrogen. Hemodynamic data collected included mean pulmonary arterial and left atrial pressures, cardiac index, and PVR.

CPB and circulatory arrest. Purse-string sutures (Ethicon Inc., Somerville, N.J.) were placed in the aortic root (5-0 Prolene suture) and right atrial appendage (2-0 silk). Animals were heparinized (500 $\mathrm{IU} / \mathrm{kg}$ ) and cannulated with a $10 \mathrm{~F}$ infant arterial cannula and a $28 \mathrm{~F}$ venous cannula (Electro-catheter Corp, Rahway, N.J.). The CPB circuit consisted of a Stockert Shiley roller pump (model 10-10-00, Shiley Inc., Irvine, Calif.), Cobe membrane oxygenator (Cobe Laboratory, Lakewood, Colo.), and a Bio-Cal 370 heat exchanger (Biomedicus, Minneapolis, Minn.). The pump circuit was primed with crystalloid and fresh donor pig blood to maintain a circuit hematocrit of $18 \%$ to $20 \%$.

The piglets were cooled over 20 minutes to a nasopharyngeal temperature of $18^{\circ} \mathrm{C}$, the hearts were arrested for 30 minutes, and the animals were then rewarmed over 30 minutes to $37^{\circ} \mathrm{C}$ and weaned from CPB. Saline slush was used for topical myocardial hypothermia during cooling and circulatory arrest. The hearts became asystolic during cooling and occasionally fibrillated during rewarming, requiring direct current eardioversion with 1 to 2 joules. No animal required more than two defibrillations. CPB circuit blood volume was returned to the animals as needed to maintain stable left atrial pressure and cardiac output after they were weaned from CPB. No inotropic agents were used. Animals were studied 15 minutes after being weaned from $\mathrm{CPB}$ while in a steady-state condition with arterial blood gas values within the limits previously described in the anesthesia section. 
Tissue RNA isolation. All tissue samples were stored at $-70^{\circ} \mathrm{C}$ and kept on dry ice during handling. Total tissue RNA was isolated from lung parenchymal tissue and pulmonary arterial samples weighing between 400 and 700 mg by the RNAzol method (RNA STAT-60, Tel-Test B, Inc., Friendswood, Tex.). RNA samples were quantitated with use of a spectrophotometer to measure absorbance at 260 and $280 \mathrm{~nm}$. Twenty-microgram aliquots were stored at $-70^{\circ} \mathrm{C}$ for later use.

Complementary deoxyribonucleic acid constructs and RNA probes. The porcine ET-1 complementary deoxyribonucleic acid (cDNA) construct consists of a $0.328 \mathrm{~kb}$ EcoR1/BamH1 fragment in pSP73 (Promega, Madison, Wis.) encoding nucleotides $98-426$ of the porcine ET-1 gene. This fragment spans the region encoding the prepro-endothelin gene. The control rat $\beta$-actin cDNA construct used was a commercially available template containing a $0.126 \mathrm{~kb} K p n \mathrm{I} / E c o \mathrm{R} 1$ fragment in the pTRIPLEscript vector (Ambion Inc., Austin, Tex.). This fragment corresponds to exon 5 of the rat $\beta$-actin gene (nucleotides 2682-2779 of Accession No. J00691). ${ }^{16}$ Linearized cDNA constructs were used to synthesize radiolabeled RNA anti-sense probes $\left({ }^{32} \mathrm{P}-\alpha \mathrm{CTP}\right.$, NEN-DuPont, Boston, Mass.) and nonradiolabeled sense controls with the use of either T7 or SP6 RNA polymerase as previously described. ${ }^{17}$

RNase protection assay. The procedure originally described by Zinn, DiMaio, and Maniatis ${ }^{18}$ with modifications reported by Berkowitz and associates ${ }^{19}$ was used with the following additional modifications. In brief, $20 \mu \mathrm{g}$ of total RNA was hybridized with $3 \times 10^{5} \mathrm{cpm}$ of ET-1 probe and $4 \times 10^{5} \mathrm{cpm}$ of simultaneously loaded rat $\beta$-actin control probe for 10 to 12 hours at $55^{\circ} \mathrm{C}$. RNase A $(40 \mu \mathrm{g} / \mathrm{ml})$ and $\mathrm{T} 1(1000 \mathrm{U} / \mathrm{ml})$ were added to each sample and allowed to incubate for 1 hour at $30^{\circ} \mathrm{C}$. After termination of the digestion with $10 \mu \mathrm{l}$ of $20 \%$ (weight/ volume) sodium dodecyl sulfate and $2.5 \mu \mathrm{l}$ of proteinase $\mathrm{K}$ $(15 \mathrm{mg} / \mathrm{ml})$, the samples were ethanol-precipitated at $-70^{\circ} \mathrm{C}$ overnight. The samples were then resuspended in gel loading buffer, heated to $95^{\circ} \mathrm{C}$ for 5 minutes, and separated on a denaturing $8 \mathrm{~mol} / \mathrm{L}$ urea $/ 6 \%$ acrylamide gel (Sequagel sequencing system, National Diagnostics, Atlanta, Ga.). Gels were dried on Whatmann filter paper (Whatmann Inc., Maidstone, United Kingdom) and placed on a PhosphorImager screen for quantitation.

Serial dilutions of ET-1 sense RNA ( $100 \mathrm{pg}, 1 \mathrm{ng}, 10 \mathrm{ng}$, $20 \mathrm{ng}$, and $50 \mathrm{ng}$ ) were included with each hybridization assay to allow interpolation of the ET-1 mRNA concentration in the unknowns. The concentrations thus derived were then normalized with use of the $\beta$-actin control to correct for any loading or quantitation error. All samples were normalized to the mean of the $\beta$-actin signals on each gel, with the belief that the mean would most closely approximate $20 \mu \mathrm{g}$ of total RNA loaded.

Endothelin protein assay. Samples of lung parenchyma weighing between 450 and $550 \mathrm{mg}$ were homogenized with a polytron in 10 volumes $(10 \mathrm{ml} / \mathrm{gm})$ of $10 \%$ (volume/ volume) acetic acid. The specimens were centrifuged at $20,000 \mathrm{~g}$ for 15 minutes to remove precipitants. A commercial endothelin-1,2 radioimmunoassay kit (NEN Research Products, DuPont, Boston, Mass.) was used to measure the endothelin protein concentration in picograms per milligrams total protein. Total protein concentration was measured with the bicinchoninic acid method (BCA protein assay, Pierce, Rockford, Ill.).

Endothelin receptor ligand binding studies. Cell membranes were isolated from lung parenchymal specimens weighing 400 to $700 \mathrm{mg}$. The tissue was first homogenized with a polytron at $20,000 \mathrm{rpm}$ for 2 to 3 minutes in lysis buffer containing $5 \mathrm{mmol} / \mathrm{L}$ Tris, $2 \mathrm{mmol} / \mathrm{L}$ ethylenediaminetetraacetic acid, and the protease inhibitors soybean trypsin inhibitor $(10 \mu \mathrm{g} / \mathrm{ml})$, benzamidine $(10 \mu \mathrm{g} / \mathrm{ml})$, leupeptin $(10 \mu \mathrm{g} / \mathrm{ml})$, and bacitracin $(200 \mu \mathrm{g} / \mathrm{ml})$. The homogenate was centrifuged at $19000 \mathrm{~g}$ for 10 minutes and the pellet was resuspended in assay buffer $(50 \mathrm{mmol} / \mathrm{L}$ Tris, $2 \mathrm{mmol} / \mathrm{L} \mathrm{MgCl}_{2}$, and protease inhibitors as just described) and filtered through a $210 \mu \mathrm{m}$ mesh filter (Spectra-mesh, VWR, Boston, Mass.). The protein concentration was determined by the bicinchoninic acid method. Stock solutions containing $1 \mathrm{mg} / 10 \mu \mathrm{l}$ of buffer were stored at $-70^{\circ} \mathrm{C}$. The stock solutions were diluted 1:10 with assay buffer and bovine serum albumin stock for a final bovine serum albumin concentration of $0.1 \%$.

Binding assays were done in triplicate on 80 to $100 \mu \mathrm{g}$ of membrane proteins. Assays were conducted in a final volume of $250 \mu$ l of assay buffer with ${ }^{125}$ I-ET-1 at 80 $\mathrm{pmol} / \mathrm{L}$ final concentration. Unlabeled ET-1 or BQ123 $\left(10^{-4}\right.$ to $10^{-14} \mathrm{~mol} / \mathrm{L}$ final concentration) was added to the radioligand before the addition of the membrane proteins to generate competition curves. The binding reaction was incubated for 6 hours at $25^{\circ} \mathrm{C}$. Bound tracer was then separated from free tracer by rapid vacuum filtration onto filter paper (glass fiber grade GFC, Whatmann International). Filters were rinsed three times with 3 to $4 \mathrm{ml}$ of $4^{\circ} \mathrm{C}$ buffer $(50 \mathrm{mmol} / \mathrm{L}$ Tris, $\mathrm{pH} 7.5)$ with use of a Brandel cell harvester (model M-48, Brandel Instruments, Gaithersburg, $\mathrm{Md}$.). The bound radioactivity was measured in a gamma counter (CobraII Autogamma, Packard, Meridien, Conn.). Saturation binding studies were done in identical fashion with either no unlabeled ligand (total binding) or $10^{-6} \mathrm{~mol} / \mathrm{L}$ unlabeled ET-1 (nonspecific binding). ${ }^{125}$ I-ET-1 was obtained from NEN-DuPont and both unlabeled ET-1 and BQ123 were obtained from Sigma Chemical (St. Louis, Mo.).

Statistical analysis. Groups were compared by oneway analysis of variance with a $p$ value less than 0.05 considered significant. Statistical analysis was done with commercially available software (Sigmastat, Jandel Corporation, San Rafael, Calif.). All data are presented as means plus or minus the standard error of the mean.

\section{Results}

Hemodynamics and arterial blood gas values. There was no significant difference between control and DHCA group animals with regard to weight $(6.7 \pm 1.2 \mathrm{~kg}$ vs $6.4 \pm 1.1 \mathrm{~kg}, p=0.87)$. The arterial blood gas, pulmonary arterial pressure, cardiac index, and PVR values immediately before tissue harvest are displayed in Table I. Although there was a statistically significant difference in the $\mathrm{pH}$, this was not considered a clinically significant difference. There was no difference in the arterial oxygen or 
Table I. Hemodynamic data

\begin{tabular}{ccccccc}
\hline Group & $p H$ & $\begin{array}{c}\mathrm{PCO}_{2} \\
(\mathrm{~mm} \mathrm{Hg})\end{array}$ & $\begin{array}{c}\mathrm{PO}_{2} \\
\left(\mathrm{~mm} \mathrm{Hg}^{2}\right.\end{array}$ & $\begin{array}{c}\mathrm{PAP} \\
\left(\mathrm{mm} \mathrm{Hg}^{2}\right.\end{array}$ & $\begin{array}{c}\mathrm{CI} \\
\left(\mathrm{ml} / \mathrm{kg}_{\mathrm{min}}\right)\end{array}$ & $\begin{array}{c}\text { PVR } \\
(\text { dyne-sec-cm }\end{array}$ \\
\hline Control & $7.47 \pm 0.01$ & $35.3 \pm 0.5$ & $227 \pm 7$ & $13.2 \pm 0.5$ & $126 \pm 9$ & $1447 \pm 264$ \\
DHCA & $7.43 \pm 0.01^{*}$ & $34.8 \pm 0.7$ & $224 \pm 7$ & $23.9 \pm 1.9^{*}$ & $110 \pm 9$ & $3088 \pm 407^{*}$ \\
$p$ Value & 0.004 & 0.38 & 0.79 & 0.00005 & 0.22 & 0.003 \\
\hline
\end{tabular}

$\mathrm{PCO}_{2}$, Carbon dioxide tension; $P \mathrm{O}_{2}$, oxygen tension; $P A P$, pulmonary arterial pressure; $\mathrm{CI}$, cardiac index.

${ }^{*} p<0.05 \mathrm{DHCA}$ vs control group (analysis of variance).

Table II. Endothelin $m R N A$ and protein levels

\begin{tabular}{|c|c|c|c|c|}
\hline Group & $\begin{array}{c}P A E T-1 \text { mRNA } \\
(p g)\end{array}$ & $\begin{array}{c}\text { Lung ET-1 mRNA } \\
(p g)\end{array}$ & $\begin{array}{l}\text { Lung ET-1 protein } \\
\text { (pg/mg total protein) }\end{array}$ & $\begin{array}{l}\text { Lung ET-1 binding sites } \\
\text { (fmoles/mg total protein) }\end{array}$ \\
\hline Control & $149 \pm 55$ & $4102 \pm 379$ & $4.4 \pm 0.2$ & $109 \pm 6$ \\
\hline DHCA & $547 \pm 111^{*}$ & $4623 \pm 308$ & $4.9 \pm 0.3$ & $135 \pm 9^{*}$ \\
\hline$p$ Value & 0.007 & 0.13 & 0.13 & 0.02 \\
\hline
\end{tabular}

$P A$, Pulmonary arterial.

" $p<0.05$ DHCA vs control group (analysis of variance).

carbon dioxide tensions. As would be expected, the pulmonary arterial pressure was significantly higher after DHCA $(13.2 \pm 0.5 \mathrm{~mm} \mathrm{Hg}$ vs $23.9 \pm 1.9 \mathrm{~mm}$ $\mathrm{Hg}, p=0.00005)$. The elevation in pulmonary arterial pressure was associated with an increase in PVR whereas the cardiac index did not change significantly.

RNA isolation. Sufficient total RNA was isolated from the lung specimens of all 24 animals for analysis by RNase protection assay in duplicate. Unfortunately, given the small size of piglet pulmonary arterial specimens, there was insufficient RNA isolated from the pulmonary artery of several animals to allow for adequate analysis. The RNase protection assay data for the pulmonary artery is therefore based on 19 animals ( 9 control and 10 DHCA).

ET-1 mRNA and protein levels. The results of the RNase protection assays and ET- 1 radioimmunoassay are summarized in Table II. ET- 1 mRNA expression was significantly increased after DHCA in the pulmonary artery $(149 \pm 55 \mathrm{pg}$ vs $547 \pm 111 \mathrm{pg}$, $p=0.007$ ), but there was no change in the lung parenchyma ( $4102 \pm 379 \mathrm{pg}$ vs $4623 \pm 308 \mathrm{pg}, p=$ 0.32 ). There was not a statistically significant change in pulmonary parenchymal ET-1 protein levels.

Endothelin receptors in the lung. Representative competitive binding curves for a control piglet lung with unlabeled ET-1 and BQ123 with ${ }^{125}$ I-ET-1 are shown in Fig. 1. These data are consistent with a single saturable ET-1-specific binding site with an approximate inhibition coefficient $\left(\mathrm{K}_{\mathrm{i}}\right)$ of 5 to 10 $\mathrm{pmol} / \mathrm{L}$. Binding was not inhibited by the $\mathrm{ET}_{\mathrm{A}^{-}}$ specific antagonist BQ123 up to concentrations of $10^{-5} \mathrm{mmol} / \mathrm{L}$. This is in contrast to representative curves from piglet aorta membranes (Fig. 2) in which two ET-1-specific binding sites were present, one of which was BQ123 sensitive. These data suggest that there is a single predominant ET-1specific binding site present in parenchymal lung tissue and that this binding site is most likely one of the $\mathrm{ET}_{\mathrm{B}}$ receptor subtypes.

Data from saturation binding studies are displayed in Table II. Data were collected from all 24 animals and all studies were conducted in triplicate. There was a significant increase in the number of ET-1-specific binding sites after DHCA (109 $\pm 6 \mathrm{fmol} / \mathrm{mg}$ protein vs $135 \pm 9 \mathrm{fmol} / \mathrm{mg}$ protein, $p=0.02)$.

\section{Discussion}

The mediators involved in the pulmonary hypertensive response to CPB with DHCA have been the focus of clinical and basic research for several years and considerable progress has been made in the identification of the mechanisms underlying this response. Pulmonary vasomotor tone is modulated by the vascular endothelium, which maintains a balance between vasodilators and vasoconstrictors. CPB with DHCA alters the balance by impairing endothelium-dependent vasodilation ${ }^{2,7,9}$ and increasing production of vasoconstrictors, $5,6,8,10$ which leads to pulmonary hypertension. Plasma levels of ET-1 are elevated after $\mathrm{CPB}^{11,12}$; however, because $90 \%$ of ET-1 is secreted by the vascular endothelium toward the vessel media, ${ }^{20}$ the significance of increased plasma levels is unclear. Local 


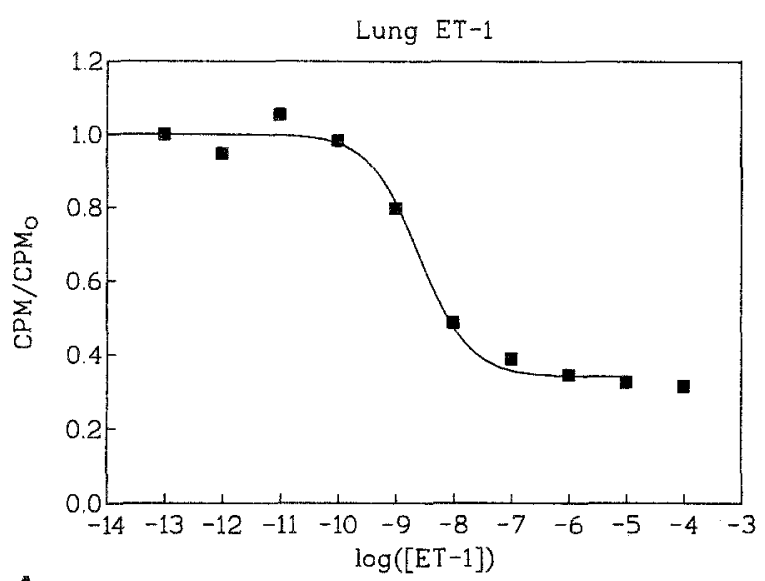

A

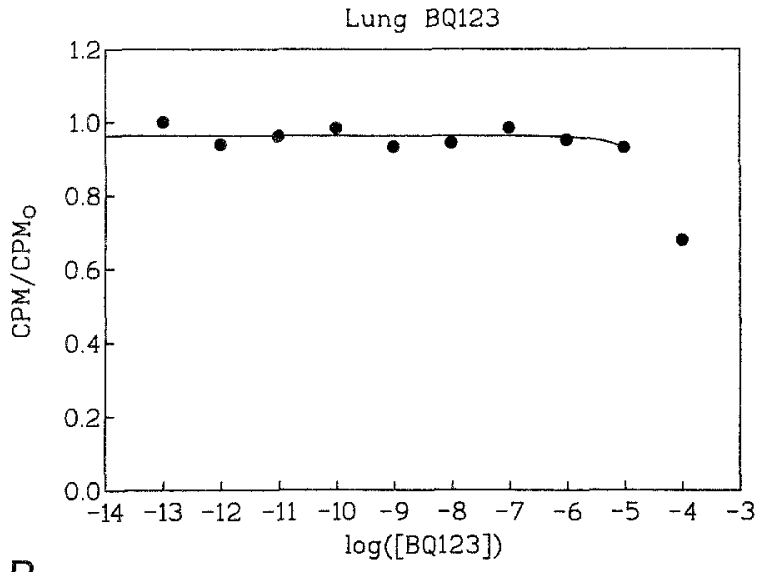

B

Fig. 1. Competition curves for specific ${ }^{125} \mathrm{I}-\mathrm{ET}-1$ binding sites using (A) ET-1 and (B) BQ123 in piglet lung. CPM, Counts per minute; $C P M_{o}$, counts per minute with no competitor (total binding). Representative curves of three experiments each done in triplicate are shown.

concentrations of ET-1 are likely more important than circulating levels in determining the response of a vascular bed. This study demonstrates that CPB with DHCA stimulates increased production of ET-1 by the pulmonary vascular endothelium. In the pulmonary vasculature, ET-1 may act as either a vasoconstrictor $^{21-23}$ or a vasodilator ${ }^{24,25}$ depending on the species, age, and baseline pulmonary vascular tone. Blockade of endothelin-converting enzyme during CPB with DHCA decreases the pulmonary hypertensive response, ${ }^{6}$ which suggests that after $\mathrm{CPB}, \mathrm{ET}-1$ acts primarily as a pulmonary vasoconstrictor.

This study also demonstrated increased expression of ET-1 receptors in the pulmonary parenchyma after CPB with DHCA. Previous reports have shown a heterogeneous distribution of ET-1

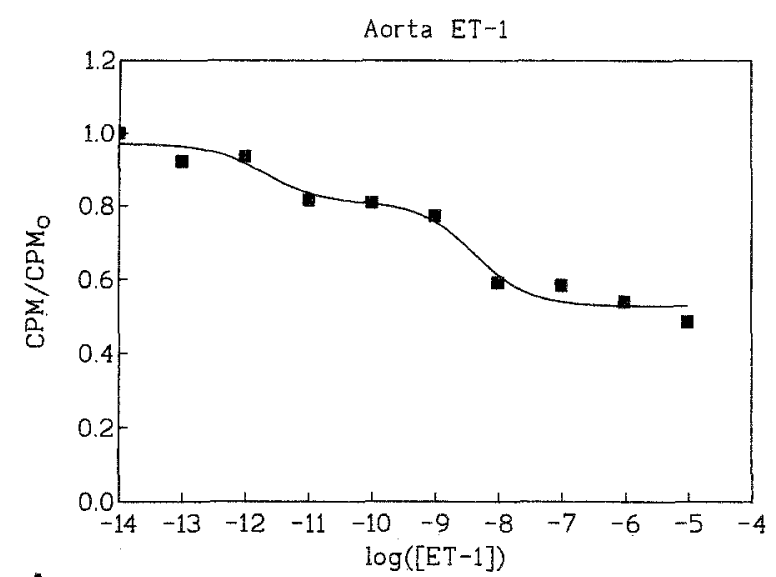

A

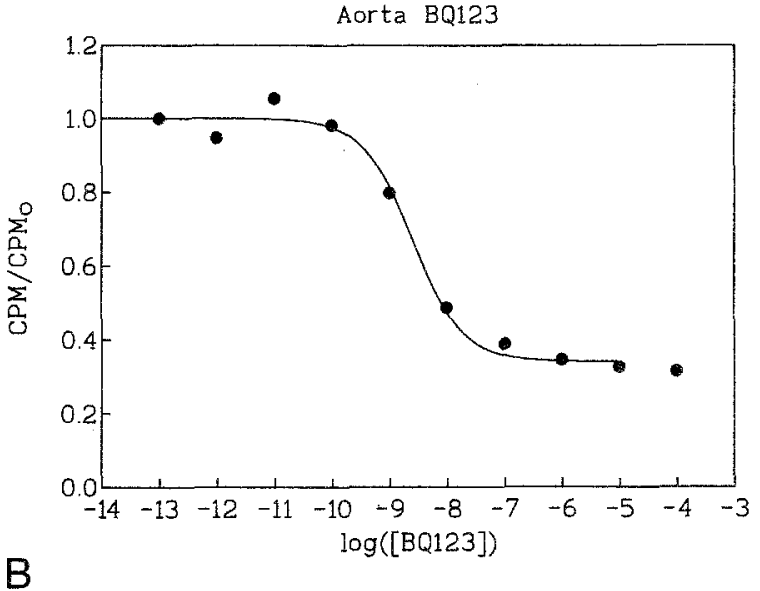

Fig. 2. Competition curves for specific ${ }^{125} \mathrm{I}-\mathrm{ET}-1$ binding sites using (A) ET-1 and (B) BQ123 in piglet aorta. CPM, Counts per minute; $C P M_{0}$, counts per minute with no competitor (total binding). Representative curves of three experiments each done in triplicate are shown.

receptor subtypes with both $\mathrm{ET}_{\mathrm{A}}$ and $\mathrm{ET}_{\mathrm{B}}$ receptors in the pulmonary artery and primarily $\mathrm{ET}_{\mathrm{B}}$ receptors in the pulmonary parenchyma. ${ }^{26,27} \mathrm{ET}_{\mathrm{A}}$ receptors are expressed primarily on vascular smooth muscle cells and initiate second messenger systems leading to vasoconstriction. ${ }^{28,29} \mathrm{ET}_{\mathrm{B}}$ receptors on vascular endothelial cells are responsible for the vasodilating effects of ET-1 through stimulation of endothelial nitric oxide production. $\mathrm{ET}_{\mathrm{B}}$ receptors on vascular smooth muscle cells, on the other hand, modulate vasoconstriction in some tissues. ${ }^{14,29}$ The predominant endothelin receptor subtype found in the pulmonary parenchyma of the piglets in this study was $\mathrm{ET}_{\mathrm{B}}$. The significance of the observed increase in $\mathrm{ET}_{\mathrm{B}}$ receptor expression in the lung parenchyma is not known. Stimulation of the $\mathrm{ET}_{\mathrm{B}}$ receptor on vascular smooth muscle cells 
can lead to vasoconstriction, thus the increase in $\mathrm{ET}_{\mathrm{B}}$ receptor expression could facilitate the vasoconstrictor effects of ET-1. Becaue $\mathrm{ET}_{\mathrm{B}}$ receptors also may be responsible for ET-1 clearance by the lung, ${ }^{30}$ the increase in pulmonary $\mathrm{ET}_{\mathrm{B}}$ receptor expression may represent a response to elevated plasma ET-1 levels.

Although the results of this study are interesting, they must be interpreted within the limitations of the study design. As with all animal models, there may be significant differences between the piglet and human pulmonary vasculature; nonetheless, prior studies with this model have produced data consistent with clinical reports. Unfortunately, the pulmonary arterial specimens from these animals were not large enough to perform ET-1 protein and receptor studies in addition to mRNA isolation, thus the effects of CPB with DHCA on ET-1 receptor expression in pulmonary arterial tissue cannot be determined from this study. Finally, although receptor density was evaluated in the pulmonary parenchyma, the specific site of receptor expression within the lung tissue was not determined nor was receptor/ second messenger coupling assayed.

The current study demonstrates increased production of ET-1 by the pulmonary vasculature and increased pulmonary parenchymal ET-1 receptor concentrations after CPB with DHCA. Previous studies have demonstrated impaired endotheliumdependent vasodilation after CPB with DHCA. These data suggest that $\mathrm{CPB}$ with DHCA results in endothelial cell injury or activation, or both, that alters the balance between endothelium-derived vasodilators and vasoconstrictors. Impairment of endothelium-dependent vasodilation coupled with increased vasoconstrictor production results in pulmonary hypertension.

\section{REFERENCES}

1. Wessel DL. Inhaled nitric oxide for the treatment of pulmonary hypertension before and after cardiopulmonary bypass. Crit Care Med 1993;21:s344-5.

2. Wessel DL, Adatia I, Giglia TM, Thompson JE, Kulik TJ. Use of inhaled nitric oxide and acetylcholine in the evaluation of pulmonary hypertension and endothelial function after cardiopulmonary bypass. Circulation $1993 ; 88(\mathrm{pt} \mathrm{1)}$ : 2128-38.

3. Schranz D, Zepp F, Iversen S, et al. Effects of tolazoline and prostacyclin on pulmonary hypertension in infants after cardiac surgery. Crit Care Med 1992;20:1243-49.

4. Komai H, Haworth SG. The effect of cardiopulmonary bypass on the lung: the injured pulmonary vascular endothelium. Perfusion 1993;8:55-62.

5. Faymonville ME, Deby-Dupont G, Larbuisson R, Deby C,
Bodson L, Limet R. Prostaglandin $E_{2}$, prostacyclin, and thromboxane changes during nonpulsatile cardiopulmonary bypass in humans. J Thorac Cardiovasc Surg 1986;91:858-66.

6. Kirshbom PM, Tsui SS, DiBernardo LR, et al. Blockade of endothelin converting enzyme reduces pulmonary hypertension after cardiopulmonary bypass and circulatory arrest. Surgery 1995;118:440-5.

7. Kirshbom PM, Jacobs MT, Tsui SS, et al. Effects of cardiopulmonary bypass and circulatory arrest on endothelium dependent vasodilation in the lung. J Thorac Cardiovasc Surg 1996;111:1248-56.

8. Shafique T, Sellke FW, Thurer RL, Weintraub RM, Johnson RG. Cardiopulmonary bypass and pulmonary thromboxane generation. Ann Thorac Surg 1993;55:724-8.

9. Shafique T, Johnson RG, Dai HB, Weintraub RM, Sellke FW. Altered pulmonary microvascular reactivity after total cardiopulmonary bypass. J Thorac Cardiovasc Surg 1993;106: 479-86.

10. Cave AC, Manche A, Derias NW, Hearse DJ. Thromboxane $\mathrm{A}_{2}$ mediates pulmonary hypertension after cardiopulmonary bypass in the rabbit. J Thorac Cardiovasc Surg 1993;106:95967.

11. Knothe CH, Boldt J, Zickmann B, Ballesteros M, Dapper F, Hempelman G. Endothelin plasma levels in old and young patients during open heart surgery: correlations to cardiopulmonary and endocrinology parameters. J Cardiovasc Pharmacol 1992;20:664-70.

12. Komai H, Adatia IT, Elliott MJ, de Leval MR, Haworth SG. Increased plasma levels of endothelin-1 after cardiopulmonary bypass in patients with pulmonary hypertension and congenital heart disease. J Thorac Cardiovasc Surg 1993;106: 473-8.

13. Nakamura S, Naruse M, Naruse K, Demura $H$, Uemura $H$. Immunocytochemical localization of endothelin in cultured bovine endothelial cells. Histochemistry 1990;94:475-7.

14. Levin ER. Endothelins. N Engl J Med 1995;333:356-63.

15. Fukuroda T, Nishikibe M, Ohta $Y$, et al. Analysis of responses to endothelins in isolated porcine blood vessels by using a novel endothelin receptor antagonist BQ-123. Life Sci 1992;50:PL107-12.

16. Nudel U, Zakut R, Shani M, Neuman S, Levy Z, Yaffe D. The nucleotide sequence of the rat cytoplasmic beta-actin gene. Nucleic Acids Res 1983;11:1759-71.

17. Titus DE. RNA transcription in vitro. In: Titus DE, ed. Promega protocols and applications guide. Madison: Promega Corporation, 1991:59-61.

18. Zinn K, DiMaio D, Maniatis T. Identification of two distinct regulatory regions adjacent to the human beta-interferon gene. Cell 1983;34:865-79.

19. Berkowitz DE, Price DT, Bello EA, Page SO, Schwinn DA. Localization of messenger RNA for three distinct $\alpha 2$-adrenergic subtypes in human tissue. Anesthesiology 1994;81:123544.

20. Rubanyi GM, Polokoff MA. Endothelins: molecular biology, biochemistry, pharmacology, physiology, and pathophysiology. Pharmacol Rev 1994;46:338-44.

21. Wang $\mathrm{Y}$, Coceani $\mathrm{F}$. Isolated pulmonary resistance vessels from fetal lambs. Circ Res 1992;71:320-30.

22. Lippton HL, Hauth TA, Summer WR, Hyman AL. Endothelin produces pulmonary vasoconstriction and systemic vasodilation. J Appl Physiol 1989;66:1008-12.

23. Minkes RK, Bellan JA, Saroyan RM, et al. Analysis of 
cardiovascular and pulmonary responses to endothelin- 1 and endothelin-3 in the anesthetized cat. J Pharmacol Exp Ther 1990;252:1118-25.

24. Perreault T, DeMartre J. Endothelin-1 has a dilator effect on neonatal pig pulmonary vasculature. J Cardiovasc Pharmacol 1991;18:43-50.

25. Chatfield BA, McMurtry IF, Hall SL, Abman SH. Hemodynamic effects of endothelin-1 on ovine fetal pulmonary circulation. Am J Physiol 1991;261:R182-7.

26. Hagiwara H, Nagasawa T, Yamamoto $T$, et al. Immunochemical characterization and localization of endothelin ET-B receptor. Am J Physiol 1993;264:R777-83.

27. Perreault T, Baribeau J. Characterization of endothelin receptors in newborn piglet lung. Am J Physiol 1995;268: L607-14.

28. Holm P, Franco-Cereceda A. Tissue concentrations of endothelins and functional effects of endothelin-receptor activation in human arteries and veins. J Thorac Cardiovasc Surg 1996;112:264-72.

29. Sumner MJ, Cannon TR, Mundin JW, White DG, Watts IS. Endothelin ET-A and ET-B receptors mediate vascular smooth muscle contraction. Br J Pharmacol 1992;107:858-60.

30. Ozaki S, Ohwaki K, Ihara M, Fukuroda T, Ishikawa K, Yano M. ET-B mediated regulation of extracellular levels of endothelin-1 in cultured human endothelial cells. Biochem Biophys Res Commun 1995;209:483-9. 